\title{
Concentration of heavy metals - iron, manganese, zinc and copper in mosses
}

\author{
K. CZARNOWSKA * and I. REJMENT-GROCHOWSKA **
}

* Department of Soil and Agricultural Chemistry, Warsaw Agricultural Academy, and ** Institute of Botany, Warsaw University

(Received: June 6, 1973)

\section{Abstract}

The iron content in gametophytes of Aulacomnium palustre. Climacium dendroides, Catharinea undulata is $5-10$ times higher than in vascular plants. The manganese, zinc and copper content is $2-3$ times higher than in vascular plants. The content of these elements in sporophytes of Catharinea undulata is approximately the same as in vascular plants. The accumulation of the investigated metals takes place mainly in the protoplasts of the chlorophyll cells of gametophyte leaves. A weakly acid pH of the medium favors accumulation. No distinct difference was found between the $\mathrm{Fe}_{2} \mathrm{O}_{3}$ content in mosses and the soil.

\section{INTRODUCTION}

Within the framework of investigations on the biological productiveness of plants, the role of certain moss species in this productiveness was checked. Common species with a wide geographical range were examined since this makes control of materials and results from various areas easier.

The main investigations concerned calculation of the biomass and production of organic matter obtained from a $1 \mathrm{~m}^{2}$ surface. The material collected was analysed chemically. Up-to-date information on the chemical composition of mosses was very restricted, therefore the interpretation of the results is difficult. At present the interest of American and Scandinavian researchers is concentrated mainly on heavy metals accumulated in mosses. Ecological work on air pollution demonstrated that mosses are good indicators of air contamination. Accumulation 
by these plants of certain metals such as lead, nickel and zinc increases with the degree of atmospheric pollution.

Investigations on the mineral composition of mosses are very interesting because their chemical composition is different from that of vascular plants. It should be stressed here that chemical analyses of vascular plants are performed on material in a different (diploid) developmental phase than those of mosses (in a haploid phase), this possibly affecting the chemical composition.

The assay of the content of some metals: $\mathrm{Fe}, \mathrm{Mn}, \mathrm{Zn}$, and $\mathrm{Cu}$ in mosses here performed is an attempt at elucidation which part of these plants accumulates these elements and of finding a relation between accumulation and the species and habitat as well as the circulation of these metals with dying of the mosses.

The chemical analyses were carried out in the Department of Soil Science and Agricultural Chemistry, Agricultural Academy, Warsaw.

\section{MATERIAL AND METHODS}

The material for analysis was taken from experimental plots chosen in April in the areas: Łąki Sierakowskie, Łąki Strzeleckie and $\mathrm{Pa}-$ protnia lying at a distance of about $80 \mathrm{~km}$ from Warsaw. The samples $100-\mathrm{cm}^{2}$ of size were collected from pure moss carpets of three species: Aulacomnium palustre, Climacium dendroides and Catharinea undulata. At the same time the soil under the moss carpet and its contact layer under the lower part of the carpet were sampled. The depth of these profiles reached from 0 to 12 and $14 \mathrm{~cm}$, all plant samples were analysed for the content of $\mathrm{Fe}, \mathrm{Mn}, \mathrm{Zn}$ and $\mathrm{Cu}$ and the results are given in milligrams/kg of dry mass. For the soil $\mathrm{pH}$ in $\mathrm{H}_{2} \mathrm{O}$ and in $\mathrm{KCl}$ was determined as well as iron.

The plant material was ashed in a muffle furnace at $500^{\circ} \mathrm{C}$, and the ash was after-burned wet with the use of small amounts of concentrated nitric, perchloric and sulphuric acid. In the solutions obtained the metals were determined in an absorption spectrophotometer. Iron in the soil was determined iodometrically after decomposition of the soil in sodium carbonate.

Mosses are an interesting material for research since they possess specific traits not noted in other plants. They have no roots, thus they can draw mineral solutions from the soil only in minute amounts. The leaves of the gametophytes consisting of one cell layer constitute a good absorption surface. As perennial plants the same population can be checked for several vegetation seasons. 


\section{RESULTS}

Analyses for $\mathrm{Fe}, \mathrm{Mn}, \mathrm{Zn}$ and $\mathrm{Cu}$ content were performed on leafy gametophytes of three species Aulacomnium palustre, Climacium dendroides and Catharinea undulata from three sites in different habitats. All the species investigated exhibited a high content of the metals for which they were analysed. The results obtained are several times higher than the analogous values reported for vascular plants. As seen from the comparison of the content of these metals in grasses and mosses, particularly iron concentration is strikingly high in mosses, 5-10 times higher than in grasses (Table 1).

Table 1

The comparison of the metals content in the mosses and grasses

\begin{tabular}{l|c|c|c|c}
\hline \multirow{2}{*}{ Name of plant group } & \multicolumn{4}{|c}{$\mathrm{ppm}$} \\
\cline { 2 - 5 } & $\mathrm{Fe}$ & $\mathrm{Mn}$ & $\mathrm{Zn}$ & $\mathrm{Cu}$ \\
\hline Mosses & $1950-2100$ & $80-310$ & $45-132$ & $5.4-31$ \\
\hline Grasses & $72-385$ & $42-118$ & $25--88$ & $5-10$ \\
\hline
\end{tabular}

The high iron content in mosses is probably the main chemical factor regulating the composition and concentration of the remaining metals and among them of those here studied $-\mathrm{Mn}, \mathrm{Zn}$, and $\mathrm{Cu}$. The important content of the latter metal is in some extent a consequence of the high concentration of iron. It is a necessary consequence for mosses in the the total processes of metabolic transformations occurring in them. The increased manganese amount in the protoplast accelerates, like in vascular plants, the oxidation of iron.

A distinct correlation r. between the concentration of heavy metals such as $\mathrm{Pb}$ and $\mathrm{Cu}, \mathrm{Cu}$ and $\mathrm{Ni}$, and $\mathrm{Cu}$ and $\mathrm{Zn}$ has been noted in the gametophytes of the moss Hypnum cupressiforme in analyses performed in Sweden (R ühling : and. Tyle r, 1969). A similar positive correlation probably occurs in mosses between the concentrations of $\mathrm{Fe}$ and $\mathrm{Mn}$.

In vascular plants the ratio of iron to manganese is evaluated approximately to be $2: 1$ and is the most favourable proportion for the development of these plants. In mosses this ratio is many times higher and specific to them, independently of the amount of these elements in the substrate (Table 2).

All the areas studied showed an acidic reaction ( $\mathrm{pH} 4.8$ to 5.8 ) both in the moss layer and in the zone of contacting soil underneath them. This value is rather uniform, therefore it is difficult to establish its influence on the mineral composition of the mosses. In the cases 
Table 2

Contents of metals: $\mathrm{Fe}, \mathrm{Mn}, \mathrm{Zn}$, and $\mathrm{Cu}$ in investigated mosses

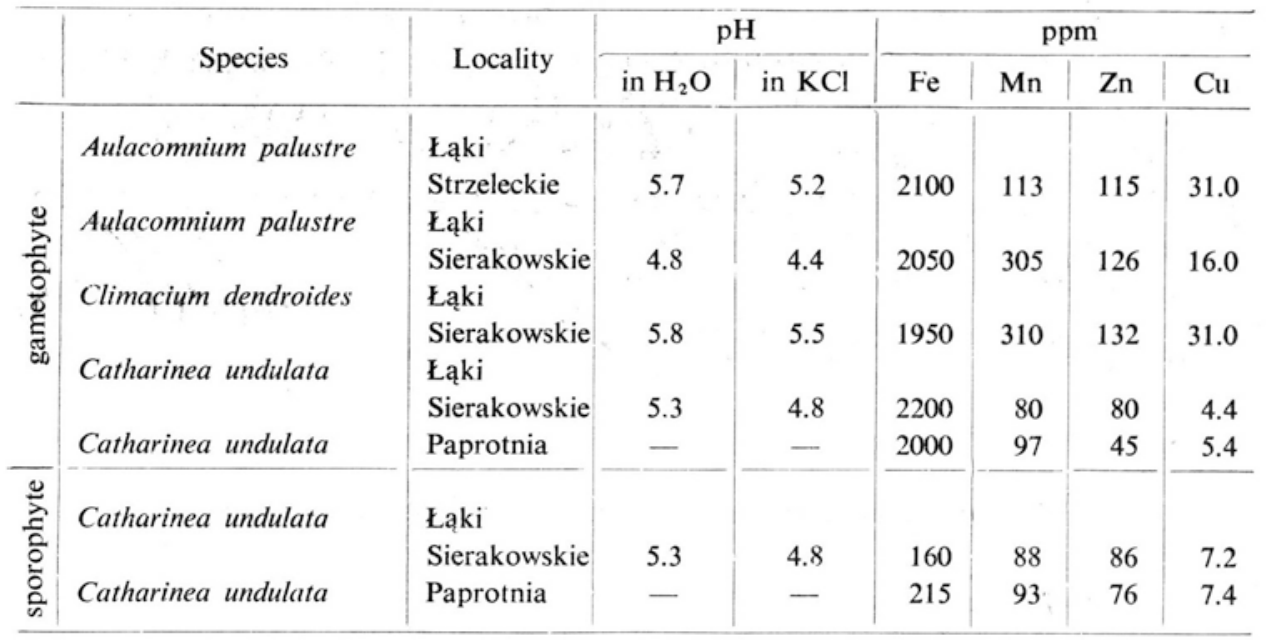

here examined it may be considered that a weakly acidic soil reaction favours accumulation of metals.

After determining the high concentration of the metals in the moss gametophytes, further analyses of the chemical composition were carried out separately for the sporophytes and the gametophytes on Catharinea undulata as exemple, collected from two habitats. The results of these analyses are very interesting, namely the sporophytes contain almost ten times less iron, $160-215 \mathrm{ppm}$, than the gametophytes. The values for the former are almost the same as for vascular plants. The ratio of iron to manganese is also lower amounting to almost $2: 1$, thus also close to that known for vascular plants. The gametophytes separated from the sporophytes contain $2000-2200 \mathrm{ppm}$ of iron.

Catharinea undulata plants were collected in autumn, the gametophytes and sporophytes were alive and contained mature spores. Sporophytes of this species, as of most mosses, are characterized by a relatively small number of chlorophyll cells, whereas they have numerous thickwalled supporting cells. It seem probable, therefore, that $\mathrm{Fe}, \mathrm{Mn}$, $\mathrm{Zn}$ and $\mathrm{Cu}$ accumulation occurs mainly in the protoplast of the chlorophyll cells of the gametophyte.

It may be evaluated on the basis of preliminary results that the iron content in moss gametophytes may increase considerably, up to 0.7 per cent of dry mass. The content of iron and of the remaining elements investigated changes with the vegetation periods, in spring it is generally lower than in July and August (Table 3). 
Tabela 3

The iron content in the mosess and in the soil

\begin{tabular}{|c|c|c|c|c|}
\hline \multirow{3}{*}{ Species } & \multirow{3}{*}{ Locality and date } & \multicolumn{3}{|c|}{ Iron content } \\
\hline & & \multicolumn{2}{|c|}{ in soil } & \multirow{2}{*}{$\begin{array}{c}\text { in mosses } \\
\mathrm{Fe}_{2} \mathrm{O}_{3} \\
\%\end{array}$} \\
\hline & & $\begin{array}{c}\text { from depth } \\
\mathrm{cm}\end{array}$ & $\begin{array}{c}\mathrm{Fe}_{2} \mathrm{O}_{3} \\
\% \\
\%\end{array}$ & \\
\hline \multirow[t]{3}{*}{ Climacium dendroides } & Łąki Strzeleckie & $0.5-1$ & 1.28 & 1.00 \\
\hline & 20.XI.1971 & $1-6$ & 1.28 & 1.00 \\
\hline & & $6-10$ & 0.88 & 1.00 \\
\hline \multirow[t]{2}{*}{ Climacium dendroides } & Łąki Sierakowskie & $0--3$ & 0.20 & 0.40 \\
\hline & 20.XI.1971 & $4-9$ & 0.44 & 0.40 \\
\hline \multirow[t]{3}{*}{ Aulacomnium palustre } & Łaki Sierakowskie & $1-4$ & 1.04 & 0.93 \\
\hline & 20.XI.1971 & $4-9$ & 0.40 & 0.93 \\
\hline & & $10-13$ & 0.24 & 0.93 \\
\hline \multirow[t]{3}{*}{ Aulacomnium palustre } & Łąki Korfowe & $0-1$ & 1.12 & 0.40 \\
\hline & 27.XI.1971 & $2-9$ & 0.53 & 0.40 \\
\hline & & $9-13$ & 0.37 & 0.40 \\
\hline
\end{tabular}

Analyses of the soil from a $0-3 \mathrm{~cm}$ depth and of the mosses do not indicate any constant and distinct difference in $\mathrm{Fe}_{2} \mathrm{O}_{3}$ content. In Climacium dendroides on Łąki Strzeleckie it reaches 1 per cent of dry mass. For the same species on Łąki Sierakowskie $\mathrm{Fe}_{2} \mathrm{O}_{3}$ content constitutes 0.40 per cent of dry mass, and the content in the soil at a $0-3 \mathrm{~cm}$ depth is 0.20 per cent.

\section{CONCLUSIONS}

A weakly acidic medium favours the accumulation of heavy metals in mosses.

Iron accumulation in moss gametophytes is almost tenfold that in vascular plants, e.g. grasses, and the content of $\mathrm{Mn}, \mathrm{Zn}$ and $\mathrm{Cu}$ is $2-3$ times higher.

Iron is probably the main factor regulating the concentration of other metals.

Moss sporophytes contain similar amounts of the metals as do vascular plants, for instance grasses.

Heavy metals are mainly concentrated in the live protoplast of the gametophyte leaves of mosses.

The lack of a distinct difference in total iron content between the mosses and the soil on which they grow indicates that iron compounds are not transferred from the gametophytes to the soil. Circulation of 
the metals investigated probably takes place mainy between the live and dead parts of the plants.

\author{
Authors' address: \\ Prof. dr Irena Rejment-Grochowska, \\ Institute of Botany, Warsaw University, \\ Al. Ujazdowskie 4, \\ 00-478 Warszawa, Poland \\ Mgr Krystyna Czarnowska \\ Department of Soil Science and Agricultural Chemistry, \\ Warsaw Agricultural Academy, \\ ul. Rakowiecka 26/30 \\ 02-532 Warszawa, Poland
}

\title{
REFERENCES
}

Czarnowska K., Pi otrowska M., 1970, Mikroelementy w żywieniu roślin. Centr. Bibl. Roln.

Maksimow A., 1954, Mikroelementy i ich znaczenfie w życiu organizmów. PWRiL.

R üh li n g A. and Tyle r G., 1968 a, An ecological approach to the lead problem Bot. Not. 121: 321-342.

Rühling A. a. Tyler G., 1969, Ecology of Heavy Metals - a Regional and Hisitorical Study, Bot. Not. 122: 248-259.

T a m m C. O. 1953, Growth yield and nutrition in carpets of a forest moss (Hylocomium splendens), Meddelanden Statens Skogsforkinungsinst. 43: 1-140.

Koncentracja niektórych metali ciężkich (żelaza, manganu, cynku, miedzi) u mchów

\section{Streszczenie}

Autorki zbadały zawartości żelaza, manganu, cynku i miedzi w gametofitach trzech gatunków mchów: Aulacomnium palustre, Climacium dendroides i Catharinea undulata i stwierdziły znacznie wyższą zawartość tych pierwiastków niż u roślin naczyniowych (Tabela 1 ).

Szczególnie wysoka jest koncentracja żelaza, jest ona 5-10-krotnie wyższa niż u traw. Ponaldto zbadano zawartość tych pierwiastków w sporofitach Catharinea undulata zebranych na dwóch stanowiskach, uzyskane wyniki są prawie 10-krotnie niższe niż dla gametofitów tego gatunku; wartości te utrzymują się prawie na takim poziomie, jak u roślin naczyniowych (Tabela 2).

Analizy porównawcze dla gametofitów i sporofitów wskazują, że kumulacja $\mathrm{Fe}, \mathrm{Mn}, \mathrm{Zn}, \mathrm{Cu}$ odbywa się głównie w protoplastach komórek chlorofilowych liści gametofitów.

$\mathrm{Na}$ badanych powierzchniach $\mathrm{pH}$ warstwy kontaktowej obumierających mohów i leżącej pod nimi gleby wynosi 4,8 do 5,8 można więc przyjąć, że słabo kwaśny odczyn sprzyja gromadzeniu metali. Natomiast górne warstwy gleby nie wykazują wyraźnej różnicy $\mathrm{w}$ zawartości $\mathrm{Fe}_{2} \mathrm{O}_{3} \mathrm{w}$ porównaniu z mchami (Tabela 3). Jest bardzo prawdopodobne, że krążenie badanych metali obywa się głównie pomiędzy żywą i obumierającą częścią gametofitu. 